\title{
SYMPOSIUM ON MEGAN DONALDSON, "THE SURVIVAL OF THE SECRET TREATY: PUBLICITY, SECRECY, AND LEGALITY IN THE INTERNATIONAL ORDER”
}

\author{
SECRET TREATIES IN INTERNATIONAL LAW AND THE FAITH OF STATES IN \\ DECENTRALIZED ENFORCEMENT
}

\author{
Danae Araria*
}

The modern law of treaties applies regardless of whether a treaty is publicized. The secrecy of an international agreement does not affect its legal force, nonpublicized agreements may be used in interpreting a publicized treaty, and mere failure to comply with domestic requirements concerning publicity does not invalidate the treaty or a state's consent to be bound by it. Under the UN Charter, UN members may not invoke an unregistered treaty or international agreement before a UN organ, but the rules on state responsibility are not concerned with the secrecy or publicity of primary obligations. Injured states may resort to countermeasures for breaches of secret treaty obligations and can suspend compliance with secret treaty obligations as a countermeasure against the responsible state. States may also seek to enforce obligations in secret treaties by bringing claims in international courts and tribunals outside the UN system—and these courts and tribunals have proliferated.

Megan Donaldson's article, The Survival of the Secret Treaty: Publicity, Secrecy, and Legality in the International Order, is a welcome and thought-provoking contribution to the scholarship on secret treaties and the rule of law. ${ }^{1}$ Secrecy has traditionally been perceived as a means by which states violate their international obligations concerning, for example, the self-determination of peoples and the prohibition of use of force. This understanding is primarily due to practice prior to and during the First World War. Modern scholarship, including Donaldson's contribution, challenges this perception. ${ }^{2}$ Although it cannot be excluded that states may use secrecy as a means for pursuing violations of international law, states also conclude secret treaties that do not violate international law (or that will not violate international law, if implemented). The rationale behind secrecy may be that if such agreements are publicized, they may undermine peace. Additionally, governments may lack sufficient personnel, which may prevent them from publicizing treaties — either domestically or internationally_and such capacity limitations may even exist in larger bureaucracies. But it is important to recognize that some of the legal "techniques" that, according to Donaldson, have supported the conclusion of secret treaties in the previous century and in this century are perfectly available in the law of treaties. Further, decentralized measures for enforcing international law, such as the rules on countermeasures under the law on state responsibility, still operate even where the primary obligations breached are secret.

This essay discusses how the law of treaties accommodates secrecy of treaties, and suggests that secret treaties may not only indicate the faith that states may have in pacta sunt servanda, as Donaldson argues, but also signal their

* Senior Lecturer in Law, Faculty of Laws, University College London (UCL).

${ }^{1}$ Megan Donaldson, The Survival of the Secret Treaty: Publicity, Secrecy, and Legality in the International Order, 111 AJIL 575 (2017).

2 See, e.g., Ashley S. Deeks, A (Qualified) Defense of Secret Agreements, 49 Ariz. S. L.J. 713 (2017).

\footnotetext{
The American Society of International Law and Danae Azaria $@$ 2018. This is an Open Access article, distributed under the terms of the Creative Commons Attribution licence (http://creativecommons.org/licenses/by/4.0/), which permits unrestricted re-use, distribution, and reproduction in any medium, provided the original work is properly cited.
} 
faith in the decentralized enforcement of international law through countermeasures under the law of state responsibility, and by recourse to international courts and tribunals that are not UN organs.

\section{Ascertaining the Existence of an International Agreement}

Under the law of treaties - as set forth in the Vienna Convention on the Law of Treaties (VCLT) - publicity (through registration with the UN Secretariat) is not a constitutive element of a treaty. ${ }^{3}$ The term "treaty" in VCLT Article 2(1)(a) is defined as "an international agreement concluded between States in written form and governed by international law, whether embodied in a single instrument or in two or more related instruments and whatever its particular designation." Article 80(1) of the VCLT requires that VCLT parties transmit treaties "after their entry into force to the UN Secretariat for registration or filing and recording, as the case may be, and for publication." States may choose not to register an instrument, because it is not an international agreement or despite the fact that it is an international agreement. In the latter case, states bear the implications of such omission under the law of state responsibility for breach of VCLT Article 80 and UN Charter Article 102, where applicable.

In Aegean Sea Continental Shelf (Greece v. Turkey) (1978), Greece relied on two instruments in support of the jurisdiction of the International Court of Justice (ICJ), including a 1975 joint communiqué between the Greek and Turkish Prime Ministers. The Court found that it was not an international agreement conferring jurisdiction on it. However, it pronounced that "whether the [communiqué] does or does not constitute such an agreement essentially depends on the nature of the act or transaction to which [it] gives expression." 4 To determine "the nature of the act," the Court had regard to "its actual terms and to the particular circumstances in which it was drawn up." 5

The ICJ has since used these criteria in other cases expressly ${ }^{6}$ (and implicitly), ${ }^{7}$ as have other international tribunals. ${ }^{8}$ These criteria introduce some objective method for ascertaining the existence of an international agreement, but they do not dispel all ambiguity, and may affect states' decisions to publicize (or not) an instrument, including through registration. However, registration (as a means of publicity) or nonregistration (as a means of secrecy) of itself is not constitutive of and does not provide evidence of the existence of an international agreement.

In Qatar v. Babrain (1994), Qatar and Bahrain each sent identical letters in December 1987 to the King of Saudi Arabia, who was mediating their dispute. The two states agreed that their identical letters constituted an international agreement. However, they disagreed about whether Minutes from December 1990 that recorded their consultations and determined what constituted their "disputed matters" were an international agreement. In order to establish its jurisdiction, the Court had to determine that both the 1987 exchange of letters and the 1990 Minutes were international agreements. Bahrain argued that the subsequent conduct of both Qatar and Bahrain demonstrated that they did not consider the 1990 Minutes to be an international agreement: Qatar never registered them with the General Secretariat of the Arab League, and registered them with the UN Secretariat only six months after it signed them, a registration to which Bahrain objected. The ICJ pronounced that "[n]on-registration or late

\footnotetext{
${ }^{3}$ Vienna Convention on the Law of Treaties, May 23, 1969, 1155 UNTS 331.

4 Aegean Sea Continental Shelf (Greece v. Turk.), 1978 ICJ REp. 3, para. 96 (Dec. 19).

${ }^{5} \underline{I d}$.

${ }^{6}$ Case Concerning Maritime Delimitation and Territorial Questions Between Qatar and Bahrain (Qatar v. Bahr.), Jurisdiction and Admissibility, 1994 ICJ ReP. 112, para. 25 (July 1).

${ }^{7}$ Maritime Delimitation in the Indian Ocean (Som. v. Kenya), Preliminary Objections para. 42 (Feb. 2, 2017).

8 "Hoshinmaru" (Japan v. Russ.), Case No. 14, Judgment of Aug. 6, 2007, 9 ITLOS Rep. 18, para. 86; Delimitation of the Maritime Boundary in the Bay of Bengal (Bangl./Myan.), Judgment of Mar. 14, 2012, 12 ITLOS Rep. 4, paras. 92-93.
} 
registration ... does not have any consequence for the actual validity of the agreement," and that it "therefore cannot infer from [Qatar's late registration and nonregistration] that Qatar considered, in December 1990, that [the Minutes were not] an international agreement."10

On the other hand, registration with the UN Secretariat by one of the parties does not provide evidence that an international agreement exists; the UN Secretariat has registered even unilateral declarations. ${ }^{11}$ However, the ICJ's reasoning in Somalia v. Kenya (2017) implies that the reaction of the other party (or parties) to registration may be relevant in assessing whether the parties have concluded an international agreement. ${ }^{12}$ In that case, the ICJ, in order to determine whether it had jurisdiction, assessed whether a memorandum of understanding (MOU) between Somalia and Kenya was a treaty in force. Kenya had registered the MOU with the UN Secretariat and Somalia had not protested against that registration for five years. The ICJ took into account Somalia's lack of protest (within sufficient time) in determining whether the MOU was a treaty—although this was not the only basis for the Court's finding: the Court first noted that the terms of the MOU were indicative of its binding character. ${ }^{13}$

The Court's reasoning in Somalia v. Kenya, where registration followed by lack of protest were relevant for ascertaining the existence of an international agreement, appears to be inconsistent with the Court's reasoning in Qatar v. Bahrain, where nonregistration or late registration were considered irrelevant, as was Bahrain's objection to Qatar's (late) registration. ${ }^{14}$ However, one way to understand the Court's reasoning is that it attached different evidentiary value to the parties' subsequent conduct (registration, nonregistration, objection, and failure to protest). In Qatar v. Bahrain, the Court may not have considered the parties' subsequent conduct to be relevant because the conduct of one state contradicted that of the other (registration followed by objection). In Somalia v. Kenya, the Court's pronouncement may indicate that where conduct of one state (failure to protest) does not contradict that of the other (registration), it may confirm the existence of an international agreement, but the existence of an agreement is determined by the actual terms of the instrument (and the circumstances in which it was drawn up).

\section{Interpretation of Treaties}

Neither the general rule on treaty interpretation nor the rule on supplementary means of interpretation in VCLT Articles 31 and 32 respectively, which set forth customary rules, ${ }^{15}$ requires states to publicize the means that the interpreter is obliged to use (under Article 31) or may have recourse to (under Article 32) in order to interpret a public or secret treaty. For instance, a secret treaty (despite the fact that it has to be registered) shall be taken into account for the interpretation of another treaty, assuming that it meets the requirements of the rule set forth in Article 31(3)(c). Moreover, VCLT Article 31(3)(a) provides that "[a]ny subsequent agreement between the parties regarding the interpretation of the treaty or the application of its provisions shall be taken into account, together with a treaty's context." This rule implicates a subsequent agreement in substance that reflects the common

\footnotetext{
${ }^{9}$ Case Concerning Maritime Delimitation and Territorial Questions Between Qatar and Bahrain (Qatar v. Bahr.), Jurisdiction and Admissibility, 1994 ICJ REP. 112, para. 29 (July 1).

${ }^{10}$ Id.

11 E.g., Declaration (with Letter of Transmittal to the UN Secretary-General) on the Suez Canal and the Arrangements for its Operation, 265 UNTS 299 (Apr. 24, 1957).

12 Kelvin Widdows, What is an Agreement in International Law? 50 BRIT. Y.B. INT'L L. 117, 143 (1979).

${ }^{13}$ The MOU contained a provision establishing its entry into force upon signature, which seems to have been the key to the Court's reasoning. Maritime Delimitation in the Indian Ocean (Som. v. Kenya), Preliminary Objections para. 42 (Feb. 2, 2017).

${ }^{14}$ However, it could be argued that in Qatar v. Babrain the Court did not consider Bahrain's objection, because it considered irrelevant Qatar's late registration in the first place.

${ }^{15}$ Dispute Regarding Navigational and Related Rights (Costa Rica v. Nicar.), 2009 ICJ ReP. 213, para. 47 (July 13).
} 
understanding of the parties concerning the treaty's interpretation and may be embodied in a nonpublished instrument, whether binding or not. ${ }^{16}$ Other means of interpretation may also not have to be publicized, such as "any instrument which was made by one or more parties in connection with the conclusion of the treaty and accepted by the other parties as [related] to the treaty." 17

\section{Invalidation of Consent to Be Bound}

Under the VCLT and customary international law, the secrecy of an international agreement does not invalidate or constitute a ground for invalidation of the treaty itself or of a state's consent to be bound by the treaty. The customary rule set forth in VCLT Article 46 permits invalidation of the consent to be bound if the consent involved a manifest breach of a domestic law rule of fundamental importance regarding the competence to conclude treaties. Such a domestic law rule could be a constitutional requirement that subjects consent to be bound to a parliamentary decision or another form of publicity. However, the threshold of invalidation of consent to be bound is high: a manifest violation (as defined in Article 46(2)) ${ }^{18}$ of such internal law is required for invalidation; a nonmanifest violation does not entail such an effect.

In Cameroon v. Nigeria (2002), the ICJ pronounced that domestic rules concerning the authority to sign treaties for a state are constitutional rules of fundamental importance, but a limitation on a head of state's capacity in this respect (and by implication the capacity of the head of government and minister of foreign affairs) is "not manifest in the sense of Article 46, paragraph 2, unless at least properly publicized." ${ }^{19}$ States are not under a general legal obligation to keep themselves informed of legislative and constitutional developments in other states. ${ }^{20}$ The fact that the constitutional requirement was public under Nigeria's domestic law did not mean that its breach was manifest under Article 46(2) of the VCLT.

\section{Consequences of Nonregistration and Decentralized Enforcement}

Consistent with the decentralized lawmaking process of international law, under both the UN Charter and the current law of treaties, nonregistration with the UN Secretariat does not affect the treaty's validity. Under Article 102(2) of the UN Charter, the consequence of nonregistration (of treaties that must be registered) is that "[n]o party to any such treaty or international agreement ... may invoke that [unregistered] treaty or agreement before any organ of the [UN]." 21 A state that does not register a particular treaty cannot benefit from the UN system, including ICJ adjudication, in order to invoke responsibility for a breach of obligations contained in that unregistered treaty. However, the term "invoke" in Article 102(2) of the UN Charter is unclear, and may include all or some of the following situations: (a) basing the ICJ's jurisdiction on unregistered treaties; (b) permitting and engaging with claims concerning the application of (and a fortiori applying) unregistered treaties; and (c) taking into account

\footnotetext{
${ }^{16}$ Int'l Law Comm'n, Text of the Draft Conclusions on Subsequent Agreements and Subsequent Practice in Relation to the Interpretation of Treaties Adopted by the Commission, Report of the International Law Commission, Sixty-eighth session (2 May-10 June and 4 July-12 August 2016), UN Doc. A/71/10, at 211-12, para. 31.

${ }^{17}$ Vienna Convention on the Law of Treaties art. 31(2)(a), May 23, 1969, 1155 UNTS 331.

${ }^{18}$ Vienna Convention on the Law of Treaties art. 46(2), May 23, 1969, 1155 UNTS 331 provides: "A violation is manifest if it would be objectively evident to any State conducting itself in the matter in accordance with normal practice and in good faith."

${ }^{19}$ Land and Maritime Boundary between Cameroon and Nigeria (Cameroon v. Nigeria: Eq. Guinea intervening), 2002 ICJ REP. 303, para. 265.

${ }^{20} I d$. at para. 266.

${ }^{21}$ UN Charter art. 102(2) (emphasis added).
} 
unregistered treaties in order to interpret registered treaties. Inconclusiveness about the meaning of "invocation" in this provision may be one reason why the ICJ has not thoroughly addressed whether and in which cases unregistered treaties may be referred to during ICJ proceedings or relied upon by the Court. Perhaps India's argument in the pending Jadhav Case (India v. Pakistan) will be an opportunity for the Court to further clarify this point. ${ }^{22}$

In any event, given the multiplicity of international courts and tribunals that are not UN organs, a state may invoke the responsibility of another state for a breach of an unregistered treaty by bringing a claim (or may otherwise invoke the treaty before other non-UN courts or tribunals), ${ }^{23}$ unless states agree otherwise. The likelihood of resorting to such means may be slim: such invocation (depending on whether the proceedings and their outputs are public) would publicize the secret treaty. Regardless, an injured state may resort to unilateral countermeasures against the responsible state for a breach of an international obligation-including a secret treaty obligation. Under the law of state responsibility, the conditions of lawfulness of countermeasures are unconcerned with the secrecy of primary obligations. They do not require that the injured state takes countermeasures only in response to a breach of a publicized obligation owed to it by the responsible state. Nor do they require that the injured state suspend compliance only with publicized obligations it owes to the responsible targeted state. ${ }^{24}$ States may take such countermeasures lawfully, assuming that they comply with the conditions of lawfulness of countermeasures under customary international law. It would not be necessary to publicize the secret treaty obligations in response to whose breach the countermeasure is taken; carrying out the obligation to call upon the responsible state to fulfil its obligation to cease the wrongful act, to make reparation and to offer guarantees of non-repetition would not necessarily publicize the secret treaty obligation. Nor is it necessary to publicize the treaty obligation whose performance is suspended as a countermeasure; the responsible state has to be notified of the decision to take countermeasures against it, but that notification will not necessarily publicize the secret treaty obligations.

\section{Conclusion: Faith in Decentralized Enforcement}

For Donaldson, state practice involving the conclusion of secret treaties denotes the belief of states in pacta sunt servanda. However, it may equally (and additionally) demonstrate that states continue to bave faith in the decentralized enforcement of international law (outside the UN system). Secret treaties may endure because there remain ample tools in international law that support their enforcement and permit their existence, validity, and legal effect on other (secret or publicized) treaties.

\footnotetext{
22 Jadhav Case (India v. Pak.), Verbatim Record of Oral Argument para. 66(b) (May 15, 2017).

23 The International Tribunal on the Law of the Sea pronounced that the unregistered Agreed Minutes were not an international agreement between Bangladesh and Myanmar delimiting their territorial sea (without addressing nonregistration). Delimitation of the Maritime Boundary in the Bay of Bengal (Bangl./Myan.), Judgment of Mar. 14, 2012, 12 ITLOS Rep. 4, para. 99.

${ }^{24}$ Int'l Law Comm'n, Text of the Draft Articles on Responsibility of States for Internationally Wrongful Acts with Commentaries Thereto art. 22 and 49-53 (and accompanying Commentaries), 2001 Y.B. In'L L. Comm’n 31-143, UN Doc. A/CN.4/SER.A/2001/ Add.1 (Part 2) (2007).
} 